\title{
THE DIAGNOSTIC METHOD OF ROLLING BEARING IN PLANETARY GEARBOX OPERATING AT VARIABLE LOAD
}

\author{
Paweł PAWLIK \\ AGH University of Science and Technology, Faculty of Mechanical Engineering and Robotics, \\ Department of Mechanics and Vibroacoustics, al. A. Mickiewicza 30, 30-059 Kraków, Poland \\ e-mail: pawlik@agh.edu.pl
}

Abstract

Diagnostics of machines operating at variable loads has been widely described in literature. The methods of analysing the vibroacoustic signals generated by such machines have been developed since the 1980s. They involve a synchronous sampling of signals which carry diagnostic information, where the sampling frequency depends on the machine rotational speed. Presently, there are many methods in the literature used for synchronization of signals with rotational speed based on signal decimation, subsampling or Gabor transform. However, these methods do not totally solve the problem of diagnosing the machines operating at various loads. The change of machine load also affects the amplitudes of diagnostic parameters.

The paper attempts to develop a diagnostic method that is independent of the system load change. The method is based on parameterization of amplitudes of characteristic orders. Single-number statistical parameters have been proposed for diagnostics of rolling bearings operating at variable loads. Tests have been conducted on a laboratory rig where the tested object was a rolling bearing on an output shaft of a planetary gearbox. The bearing was damaged by removing the grease which is a frequent type of damage in industry and can lead to a quick bearing seizure.

Keywords: vibroacoustic diagnostics, bearing diagnostics, order analysis, variable load.

\section{METODA DIAGNOZOWANIA ŁOŻYSKA TOCZNEGO PRZEKŁADNI PLANETARNEJ PRACUJĄCEJ PRZY ZMIENNYM OBCIĄŻENIU}

\section{Streszczenie}

Diagnostyka maszyn pracujących przy zmiennym obciążeniu jest problemem szeroko opisywanym w literaturze. Metody analizy sygnałów wibroakustycznych pochodzący od tego typu maszyn rozwijane były już od lat 80-tych. Polegają one na synchronicznym próbkowaniu sygnałów niosących informację diagnostyczną, gdzie zmienna częstotliwość próbkowania zależy od sygnału prędkości obrotowej diagnozowanej maszyny. Obecnie w literaturze znaleźć można wiele metod służących do synchronizacji sygnałów z prędkością obrotową opartych na decymacji sygnału, subsamplingu czy transformacji Gabora. Jednak zastosowanie tych metod nie rozwiązuje do końca problemu diagnozowania maszyn pracujących przy zmiennym obciążeniu. Zmiana obciążenia maszyny ma również wpływ na zmianę wartości amplitud parametrów diagnostycznych.

W pracy podjęto problem opracowania metody oceny stanu technicznego niewrażliwej na zmianę obciążenia badanego układu. Metoda bazuje na parametryzacji przebiegów amplitud rzędów charakterystycznych. Zaproponowano jednoliczbowe parametry statystyczne do diagnozowania łożysk tocznych pracujących przy zmiennym obciążeniu. Przeprowadzono badana na stanowisku laboratoryjnym gdzie badanym obiektem było łożysko toczne na wale wyjściowym przekładni planetarnej. Diagnozowane łożysko uszkodzono poprzez wypłukanie smaru, co jest często spotykanym uszkodzeniem w przemyśle i może prowadzić do szybkiego zatarcia łożyska.

Słowa kluczowe: diagnostyka wibroakustyczna, diagnostyka łożysk, analiza rzędów, zmienne obciążenie.

\section{INTRODUCTION}

The rolling bearing diagnostics is a problem widely described in literature. This type of diagnostics is based on the temperature or vibration measurements [1]. For the method to be effective, an appropriate signal analysis should be performed with the use of methods in the time or frequency domain. In most cases required are more advanced diagnostic methods based on the statistical analysis or envelope analysis [2, 3], and also on the wavelet analysis [4, 5]. In the analysis of the signal envelope, it is significant to select the frequency band for which this analysis is to be carried out. For this purpose, the kurtogram method described in works $[6,7,8]$, as well as other developed methods based on genetic algorithms [9] or adaptive wavelet method [10] can be used.

If the diagnosed bearing is in a machine operating at variable loads, also synchronous 
methods should be used that allow synchronization of diagnostic signals with rotational speed. The synchronous methods allow eliminating the impact of system load in the frequency domain [11, 12]. However, the load also affects the vibration signal amplitude [13] and consequently the amplitudes of determined orders. The changes of system loads should be accounted for in the diagnostic method. In [14], the authors determined the relationship between the amplitudes of vibration acceleration orders and the rotational speed for various load levels which has significantly improved the diagnostics effectiveness. In $[15,16]$ the artificial intelligence methods were used for diagnosing the machines operating at variable loads. Complex Bayesian inference [17] was also used in detection of damage type for various load and rotational speed variants [18]. The other approach was a method of separating the components related to the variable rotational speed and load [19].

This paper presents a diagnostic method of a rolling bearing in a planetary gearbox operating at variable loads. The damage involved the removal of grease which often occur in industry. A synchronous analysis of the vibroacoustic signal envelope was performed. The relationship between the amplitude of characteristic orders and the drive load was determined. Single-number statistical parameters for rolling bearing diagnostics were proposed. The possibility of rolling bearing diagnostics by analysing the synchronized envelope signal for the gearbox meshing band was analysed too.

\section{TESTING RIG}

The testing rig comprises a planetary gearbox (ratio 4:1), drive motor and a braking motor. The supply frequency was set by frequency converters controlled by means of a measurement card. The use of measurement card with analogue outputs supported by an application designed in the LabVIEW environment allows setting the rotational speed and any function of the gearbox load torque.

Two acceleration sensors were used in the gearbox diagnostics: a triaxial PCB 356B08 accelerometer installed in the gearbox body and a PCB 600A12 accelerometer installed on the gearbox bearing seat. The temperature was controlled by an LM35 temperature transmitter, all measurements were made at the same gearbox temperature of $38^{\circ} \mathrm{C}$. The rotational speed was measured with a DT-2234C+ tachometer with analogue output. The data were recorded using a NI PXIe-8133 controller placed in a NI PXIe-1062Q enclosure with measurement cards: NI PXI-4472B - measurement of vibration acceleration and rotational speed, NI PXIe-6361 - temperature measurement. The measuring signals were recorded with the sampling frequency equal to $96 \mathrm{kHz}$. The analysis was carried out for signals with a length of 120 seconds for a properly working machine and with introduced damage. The testing rig and the placement of measuring sensors is presented in (Fig. 1).

The damage involved a removal (rinsing out) of grease from the gearbox output shaft bearing, this was a $3205 \mathrm{~A}$ double-row bearing. The grease loss is a frequently occurring damage. The damaged bearing is shown in Fig. 2.

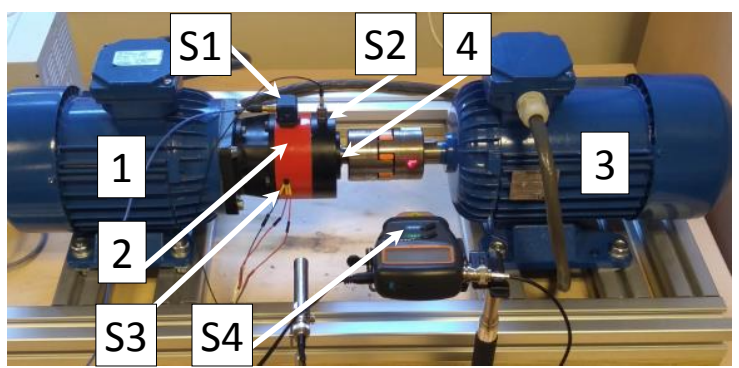

Fig. 1. Testing rig and the placement of measuring sensors, 1) drive motor, 2) planetary gearbox, 3) braking motor, 4) seat with damaged bearing, S1) acceleration sensor on the gearbox body, S2) acceleration sensor on the bearing seat, $\mathrm{S} 3$ ) temperature sensor, S4) tachometer

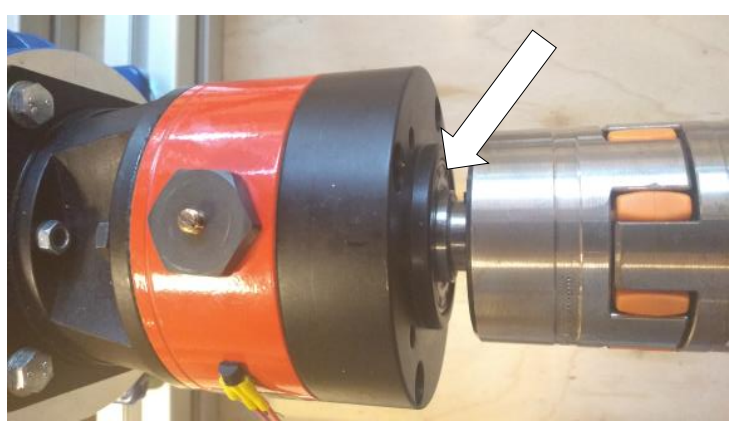

Fig. 2. 3205A bearing with damage (grease rinsed out) on the planetary gearbox output shaft

A variable sinusoidal load was applied in order to analyse the impact of the operating conditions on then tested system: the load varied from maximum of $4.2 \mathrm{Nm}$ and minimum of $1.6 \mathrm{Nm}$. The rotational speed and corresponding torque values are presented in Fig. 3.

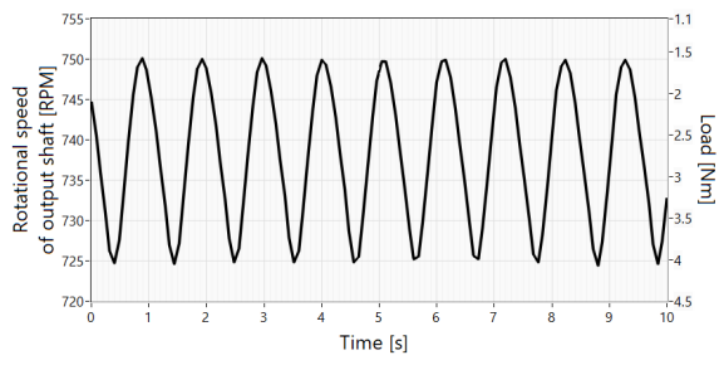

Fig. 3. Rotational speed of the output shaft in the system with sinusoidal load. The corresponding load torque values are indicated on the vertical axis on the right-hand side 


\section{SIGNAL ANALYSIS METHOD}

The vibration acceleration was measured on the gearbox body and the output shaft bearing seat. The damaged bearing was installed in the seat. Due to a variable character of the load, the signals were analysed using the order analysis method which is based on resampling of the vibration time signal relative to the output shaft rotational speed. Fig. 4 presents a diagram of the order analysis algorithm. In phase one, the tachometer signal in subjected to interpolation on a cascaded integrator-comb (CIC). Then, the filtered tachometer signal is used as a basis for the resampling of the vibration signal in order to determine the vibration signal relative to the rotation angle (Even Angle Signal). Such resampled signal can be subjected to the Fast Fourier Transform (FFT). The transform changes the frequency into numbers of orders which correspond to the multiples of the shaft rotational speed [20]. The analysis result can also be the amplitude and phase of a given order as a function of time or frequency. In the analysed case, the measurement was made on the output shaft, and hence the numbers of orders correspond to the multiples of the output shaft frequency.

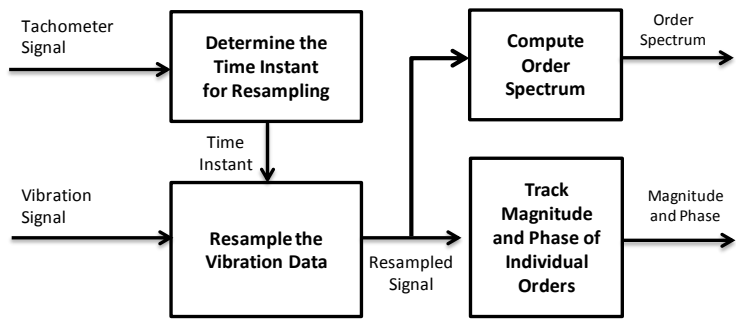

Fig. 4. Diagram of order analysis algorithm

[20]

The order analysis significantly facilitates the diagnostics of machines operating at variable loads because instead of observing the entire band it is sufficient to observe one parameter which is the amplitude of a given order. However, in the rolling bearing diagnostics, the spectral analysis of the resampled signal alone does not give desirable results. An effective tool is the signal envelope performed in the appropriate band [21]. The band can be selected using spectral kurtosis [22][6]. The spectral kurtosis can be determined by Short-time Fourier Transform (STFT):

$$
S(t, f)=\int_{-\infty}^{+\infty} x(t) w(t-\tau) e^{-2 \pi f t} d t
$$

where $w(t)$ is a time window function, $x(t)$ is a time signal. The spectral kurtosis can be written as dependencies [22]:

$$
K(f)=\frac{\left\langle|S(t, f)|^{4}\right\rangle}{\left\langle|S(t, f)|^{2}\right\rangle^{2}}-2, \quad f \neq 0,
$$

where $<>$ is the time-average operator. A very important element is the selection of the STFT time window length. The STFT window must be shorter than the individual pulses. An effective method of choosing the length of the time window is the kurtogram method. The kurtogram presents the spectral kurtosis in the colormap for different lengths of the STFT time window.

The envelope signal spectrum includes information about the rolling bearing damage. By observing the amplitudes of characteristic components, it is possible to obtain information about the damage of bearing components. The characteristic frequencies for rolling bearings can be determined using the formulas below [7]:

- ballpass frequency, outer race

$$
B P F O=\frac{n f_{r}}{2}\left(1-\frac{d}{D} \cos \phi\right),
$$

- ballpass frequency, inner race

$$
B P F I=\frac{n f_{r}}{2}\left(1+\frac{d}{D} \cos \phi\right),
$$

- fundamental train frequency (cage speed)

$$
F T F=\frac{f_{r}}{2}\left(1-\frac{d}{D} \cos \phi\right),
$$

- ball spin frequency:

$$
B S F=\frac{D f_{r}}{2 d}\left[1-\left(\frac{d}{D} \cos \phi\right)^{2}\right] .
$$

where $f_{r}$ is the shaft frequency, $n$ is the number of rolling elements, and $\phi$ is the angle of the load from the radial plane, $D$ is the pitch diameter, $d$ is diameter of the rolling element.

In machines operating at variable loads, the change of amplitudes of characteristic components can be affected by the load change. The focus was on the analysis of relationships of amplitudes of characteristic components determined from the spectrum of signal envelope orders. A similar approach to the analysis of amplitudes of characteristic order can be found in [23]. For the rolling bearing diagnostics, the paper uses the algorithm presented in the previous author's paper.

In the first algorithm step, the pairs of measured momentary values (rotational speed and order amplitude) are sorted by rotational speed in the ascending order. In the next step, the average values of rotational speed and order amplitudes are determined from $N$ neighbouring samples, according to the following formulas:

$$
\begin{gathered}
\bar{s}_{i}=\frac{1}{N} \sum_{n=i N}^{i N+N} s_{n} \\
\bar{A}(r)_{i}=\frac{1}{N} \sum_{n=i N}^{i N+N} A(r)_{n}
\end{gathered}
$$

where:

$s_{n}-$ momentary rotational speed [RPM], 
$\bar{s}_{i}-$ the $i$-th average value of rotational speed for $N$ successive samples [RPM],

$A(r)_{n}$ - momentary amplitude of the $r$-th order $\left[\mathrm{m} / \mathrm{s}^{2}\right]$,

$\bar{A}(r)_{i}-i$-th average value of the amplitude of the $r$-th order for $N$ successive samples $\left[\mathrm{m} / \mathrm{s}^{2}\right]$.

Then, the match is made using the nth order polynomial, obtaining the relationship between the rotational speed and the order amplitude in the form of function. The algorithm diagram is presented in Fig. 5.

The equation of polynomial curve determined for the correct operation of the machine can be used as a standard. For the sake of the paper, used was a measure of the curve deviation from the standard curve. The difference between curves is determined based on the RMSD as per the following formula [23]:

$$
R M S D(r)=\sqrt{\frac{1}{N} \sum_{s=1}^{N}\left(A(r, s)-A_{G}(r, s)\right)^{2}}
$$

where:

$A_{G}(r, s)$ - standard amplitude for current rotational speed $(s)$ of the $r$-th order, determined from the functional relationship $\left[\mathrm{m} / \mathrm{s}^{2}\right]$;

$A(r, s)$ - current amplitude for current rotational speed $(s)$ of the $r$-th order, determined from the functional relationship $\left[\mathrm{m} / \mathrm{s}^{2}\right]$.



Fig. 5. Algorithm for determination of functional relationship between the rotational speed and characteristic orders [23]

The second parameter is the maximum difference between the standard amplitude and the current amplitude for the entire range of rotational speed:

$$
\Delta A(r)_{\max }=\left|A(r, s)-A_{G}(r, s)\right|_{\max }
$$

In order to make these parameters independent of the vibration values, the normalized measures were used as proposed in [23] where the differences between the current and standard amplitude were divided by the standard amplitude:

$$
\begin{gathered}
r R M S D(r)=\sqrt{\frac{1}{N} \sum_{s=1}^{N}\left(\frac{A(r, s)-A_{G}(r, s)}{A_{G}(r, s)}\right)^{2}} \\
r \Delta A(r)_{\max }=\left|\frac{A(r, s)-A_{G}(r, s)}{A_{G}(r, s)}\right|_{\max }
\end{gathered}
$$

\section{SIGNAL ANALYSIS RESULTS}

\subsection{Diagnostics of rolling bearing technical condition}

Firstly, the spectral kurtosis was determined [7] in order to determine the bands for which the envelope analysis should be performed. In order to correctly choose the length of the STFT window to determine kurtosis, the kurtogram method can be used. This method consists in presenting the results of the spectral kurtosis analysis in the colormap for different window length. Fig. 6 shows a kurtogram for the vibration acceleration signal for a system with a non-lubricated bearing. Higher kurtosis values can be observed for frequencies below 4000 $\mathrm{Hz}$. And the most optimal time window length is $0.16 \mathrm{~s}$, because kurtosis achieves the highest values for this length. This can be observed on the kurtogram shown for the frequency band from 200 $\mathrm{Hz}$ to $1900 \mathrm{~Hz}$ (Fig 7).

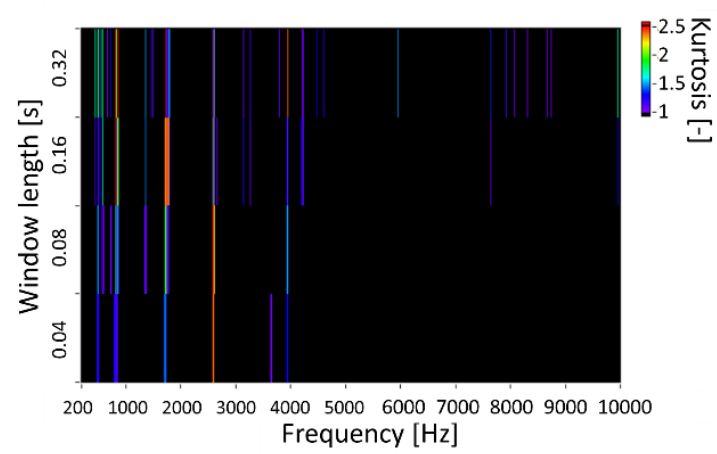

Fig. 6. Kurtogram for the vibration acceleration signal for the bearing without lubrication

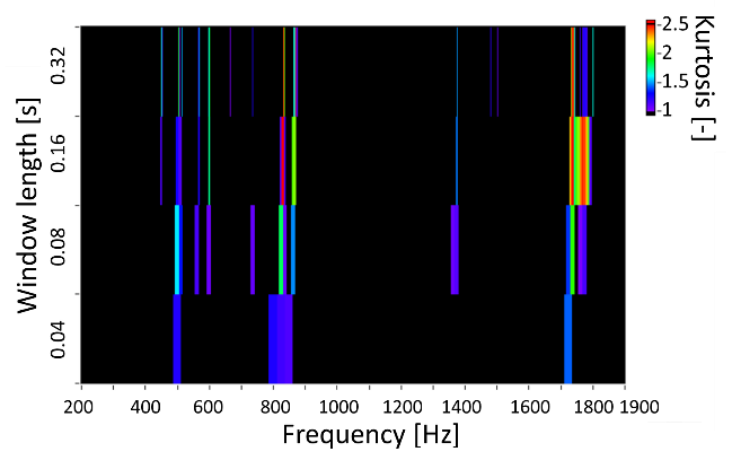

Fig. 7. Kurtogram for the vibration acceleration signal for the bearing without lubrication $(200-1900 \mathrm{~Hz})$ 
In the next step spectral kurtosis was determined for the window length of $0.16 \mathrm{~s}$ for the signal of vibration acceleration in the vertical direction. One can observe a significant increase of spectral kurtosis for the planetary gearbox meshing bands; for the drive motor supply frequency of $49 \mathrm{~Hz}$ it is the middle frequency equal to $882 \mathrm{~Hz}$. An increase of this value can also be observed for the second and third harmonic of this characteristic frequency (Fig. 8). The spectral kurtosis increases also for the 200-600Hz band.



Fig. 8. Spectral kurtosis for the undamaged bearing and the bearing without lubrication

The first step was to determine the envelope signal in the $200-600 \mathrm{~Hz}$ band, to determine the order spectrum and carry out the algorithm for determination of the functional relationship between the rotational speed and characteristic orders presented in Fig. 5. Order spectra were determined with a resolution of 0.01 order. Fig. 9 shows the envelope order spectrum of vibration acceleration for the $200-600 \mathrm{~Hz}$ band. A significant increase of the order corresponding to the FTF and BPFI can be noticed. Characteristic orders determined for the tested bearing are presented in Table 1.

Table 1. Characteristic orders for the 3205A bearing

\begin{tabular}{|c|c|}
\hline & Characteristic Order \\
\hline $\begin{array}{c}\text { Ballpass frequency, } \\
\text { outer race BPFO }\end{array}$ & 3.69 \\
\hline $\begin{array}{c}\text { Ballpass frequency, } \\
\text { inner race BPFI }\end{array}$ & 5.3 \\
\hline $\begin{array}{c}\text { Fundamental train frequency } \\
\text { (cage speed) FTF }\end{array}$ & 0.41 \\
\hline Ball spin frequency BSF & 2.34 \\
\hline
\end{tabular}



Fig. 9. Envelope order spectrum of vibration acceleration for the $200-600 \mathrm{~Hz}$ band
Because the tested machine operated at sinusoidal variable load, the relationships between the orders amplitudes and the rotational speed were determined. The rotational speed change is inversely proportional to the torque change if a constant supply frequency is fed to the motor.

The analysis of the order responsible for cage speed FTF (order No. 0.41) presented in Fig. 10 indicates a significant amplitude difference between the correct operation (black) and operation without lubrication (green). After 30 and 60 minutes of operation, the amplitude increases again (red and grey).

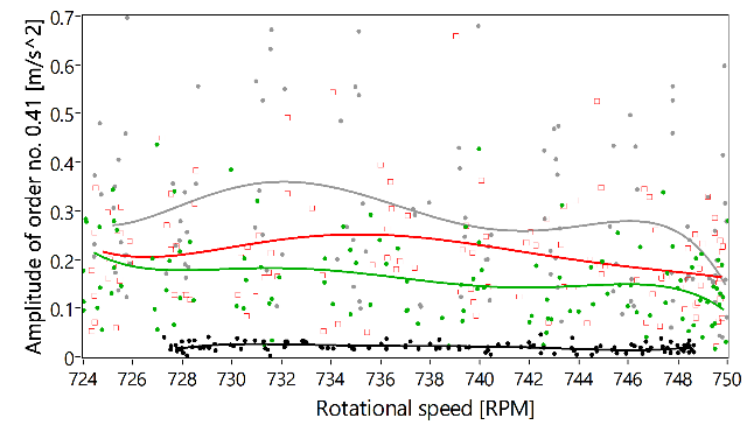

Fig. 10. Amplitude of order No. 0.41 as a function of rotational speed of the vibration acceleration signal envelope (band 200-600Hz), sensor on the bearing seat (vertical direction); black - undamaged bearing, green - bearing without lubrication, red - after $30 \mathrm{~min}$ for operation, grey - after $60 \mathrm{~min}$

A more significant amplitude increase takes place for the order related to the action of rolling elements on the inner race BPFI (order No. 5.3) (Fig. 11), however the amplitude does not increase during further operation of the unlubricated bearing. Situation for order No. 1 shown in Fig. 12 is similar.

Single-number statistical parameters presented in Table 2, Table 3, Table 4 were used to show these relationships. The RMSD parameter describes the root mean square standard deviation determined during the correct bearing operation. For the FTF order (Table 2), this parameter gradually increases along with the operation time, similarly to parameter $\Delta A_{\max }$ which describes the maximum deviation from the standard curve. For orders No. 5.3 (Table 3) and No. 1 (Table 4), these parameters do not change significantly during the operation with damage as shown in Fig. 11, Fig. 12. The high values of these parameters indicate the bearing damage.

The procedure of determination of the relationship of characteristic orders was also performed for the second harmonic of meshing band $(1600-1900 \mathrm{~Hz})$. The curves plotted for the damaged bearing signal envelope also differ significantly from the standard curve recorded during the correct bearing operation. However, the 


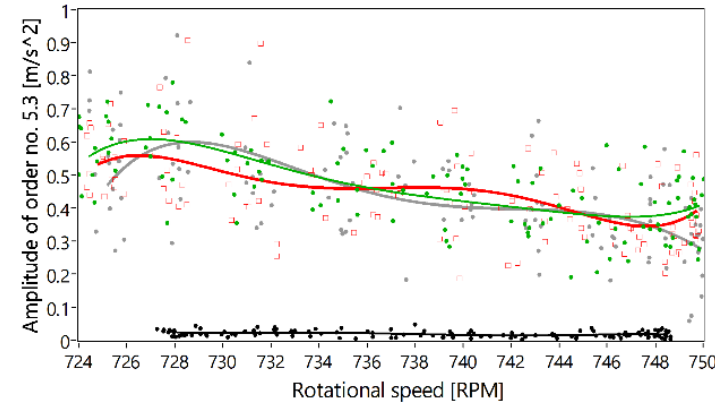

Fig. 11. Amplitude of order No. 5.3 as a function of rotational speed of the vibration acceleration signal envelope (band $200-600 \mathrm{~Hz}$ ), sensor on the bearing seat (vertical direction) ; black - undamaged bearing, green - bearing without lubrication, red after $30 \mathrm{~min}$ for operation, grey - after $60 \mathrm{~min}$

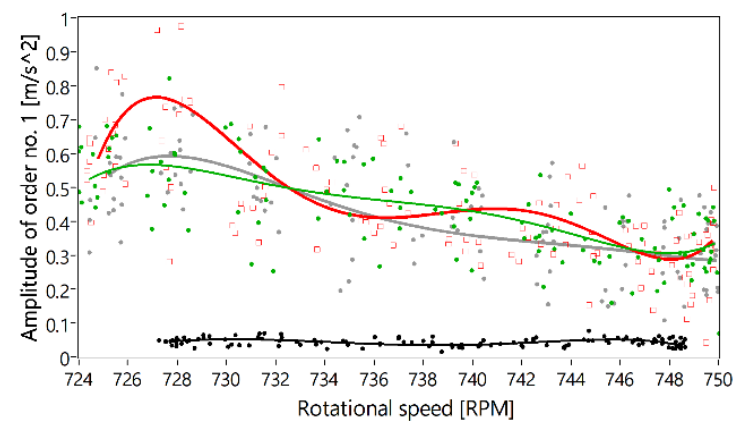

Fig. 12. Amplitude of order No. 1 as a function of rotational speed of the vibration acceleration signal envelope (band $200-600 \mathrm{~Hz}$ ), sensor on the bearing seat (vertical direction) ; black - undamaged bearing, green - bearing without lubrication, red after $30 \mathrm{~min}$ for operation, grey - after $60 \mathrm{~min}$

order amplitude is more dependent on the load than in the previous case. Fig. 13 indicates that for a higher rotational speed the differences between the damaged bearing curve and the standard curve are greater. Also, if the bearing was diagnosed using only this parameter for the loaded system (speed about 728 RPM), one might not notice significant differences in amplitude. An interesting case can be observed for order No. 1 where the curve changes into monotonicity in case of damage (Fig. 14).

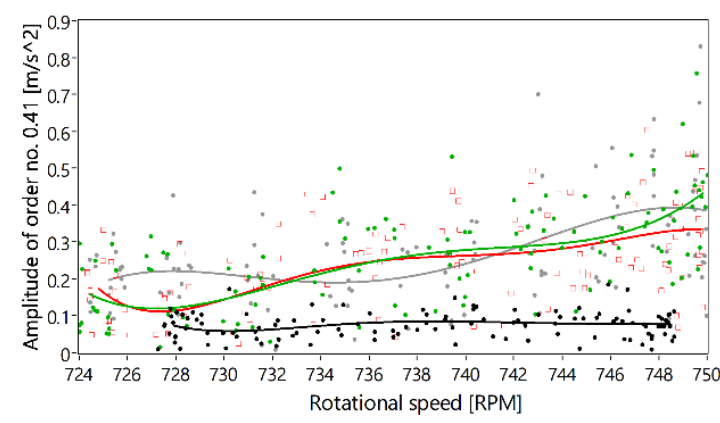

Fig. 13. Amplitude of order No. 0.41 as a function of rotational speed of the vibration acceleration signal envelope (band 1600-1900Hz), sensor on the gearbox body (vertical direction); black undamaged bearing, green - bearing without lubrication, red - after 30 min for operation, grey after $60 \mathrm{~min}$

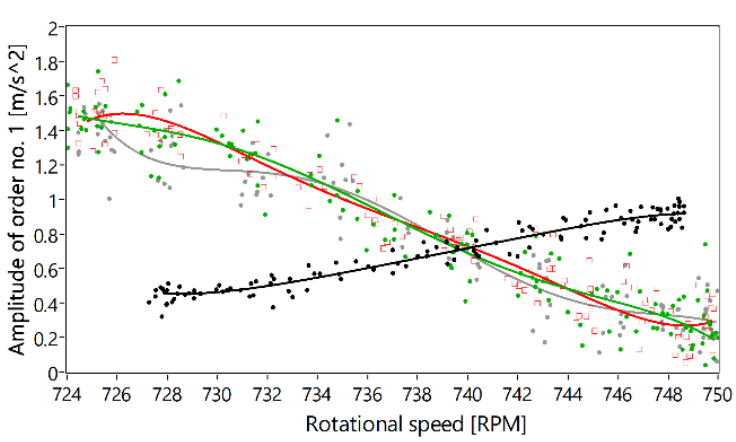

Fig. 14. Amplitude of order No. 1 as a function of rotational speed of the vibration acceleration signal envelope (band 1600-1900Hz), sensor on the gearbox body (vertical direction) ; black undamaged bearing, green - bearing without lubrication, red - after 30 min for operation, grey after $60 \mathrm{~min}$

Table 2. Statistical parameters determined based on the order amplitude FTF No. 0.41 - envelope band 200-

\begin{tabular}{|c|c|c|c|c|}
\hline & $\begin{array}{c}R M S D \\
{\left[\mathrm{~m} / \mathrm{s}^{2}\right]}\end{array}$ & $\begin{array}{c}\Delta A_{\max } \\
{\left[\mathrm{m} / \mathrm{s}^{2}\right]}\end{array}$ & $\begin{array}{c}r R M S D \\
{[-]}\end{array}$ & $\begin{array}{c}r \Delta A_{\max } \\
{[-]}\end{array}$ \\
\hline Undamaged bearing & 0.40 & 0.02 & 0.01 & 1.94 \\
\hline $\begin{array}{c}\text { Bearing without } \\
\text { lubrication }\end{array}$ & 7.59 & 0.17 & 0.14 & 21.55 \\
\hline $\begin{array}{c}\text { Bearing without } \\
\text { lubrication after 30 } \\
\text { minutes of operation }\end{array}$ & 10.55 & 0.23 & 0.20 & 24.84 \\
\hline $\begin{array}{c}\text { Bearing without } \\
\text { lubrication after 60 } \\
\text { minutes of operation }\end{array}$ & 14.82 & 0.33 & 0.29 & 35.81 \\
\hline
\end{tabular}

Table 3. Statistical parameters determined based on the order amplitude No. 5.3 - envelope band $200-600 \mathrm{~Hz}$

\begin{tabular}{|c|c|c|c|c|}
\hline & $\begin{array}{c}R M S D \\
{\left[\mathrm{~m} / \mathrm{s}^{2}\right]}\end{array}$ & $\begin{array}{c}\Delta A_{\max } \\
{\left[\mathrm{m} / \mathrm{s}^{2}\right]}\end{array}$ & $\begin{array}{c}r R M S D \\
{[-]}\end{array}$ & $\begin{array}{c}r \Delta A_{\max } \\
{[-]}\end{array}$ \\
\hline Undamaged bearing & 0.21 & 0.01 & 0.01 & 0.40 \\
\hline $\begin{array}{c}\text { Bearing without } \\
\text { lubrication }\end{array}$ & 23.50 & 0.58 & 0.46 & 26.97 \\
\hline $\begin{array}{c}\text { Bearing without } \\
\text { lubrication after 30 } \\
\text { minutes of operation }\end{array}$ & 23.32 & 0.53 & 0.44 & 29.45 \\
\hline $\begin{array}{c}\text { Bearing without } \\
\text { lubrication after 60 } \\
\text { minutes of operation }\end{array}$ & 23.33 & 0.58 & 0.45 & 26.75 \\
\hline
\end{tabular}

Table 4. Statistical parameters determined based on the order amplitude No. 1 - envelope band $200-600 \mathrm{~Hz}$

\begin{tabular}{|c|c|c|c|c|}
\hline & $\begin{array}{c}R M S D \\
{\left[\mathrm{~m} / \mathrm{s}^{2}\right]}\end{array}$ & $\begin{array}{c}\Delta A_{\max }\left[\mathrm{m} / \mathrm{s}^{2}\right] \\
{[-]}\end{array}$ & $\begin{array}{c}r R M S D \\
{[-]}\end{array}$ \\
\hline Undamaged bearing & 0.12 & 0.01 & 0.01 & 0.23 \\
\hline $\begin{array}{c}\text { Bearing without } \\
\text { lubrication }\end{array}$ & 9.47 & 0.53 & 0.41 & 12.69 \\
\hline $\begin{array}{c}\text { Bearing without } \\
\text { lubrication after 30 } \\
\text { minutes of operation }\end{array}$ & 10.12 & 0.72 & 0.45 & 17.48 \\
\hline $\begin{array}{c}\text { Bearing without } \\
\text { lubrication after 60 } \\
\text { minutes of operation }\end{array}$ & 8.82 & 0.55 & 0.39 & 13.22 \\
\hline
\end{tabular}


Single-number statistical parameters determined from the signal envelope spectrum in the 1600$1900 \mathrm{~Hz}$ band (Table 5, Table 6) do not change drastically, but the relative parameter $r \Delta A_{\max }$ shows even a 3-fold amplitude increase which may be a sign of damage. The analyses prove that it is possible to diagnose the gearbox bearings based on the envelope signal from the meshing band.

Table 5. Statistical parameters determined based on the amplitude of order No. 0.41 - envelope band 1600-

\begin{tabular}{|c|c|c|c|c|}
\hline & $\begin{array}{c}R M S D \\
{\left[\mathrm{~m} / \mathrm{s}^{2}\right]}\end{array}$ & $\begin{array}{c}\Delta A_{\max } \\
{\left[\mathrm{m} / \mathrm{s}^{2}\right]}\end{array}$ & $\begin{array}{c}r R M S D \\
{[-]}\end{array}$ & $\begin{array}{c}r \Delta A_{\max } \\
{[-]}\end{array}$ \\
\hline Undamaged bearing & 0.13 & 0.04 & 0.01 & 0.76 \\
\hline $\begin{array}{c}\text { Bearing without } \\
\text { lubrication }\end{array}$ & 2.16 & 0.26 & 0.17 & 3.28 \\
\hline $\begin{array}{c}\text { Bearing without } \\
\text { lubrication after 30 } \\
\text { minutes of operation }\end{array}$ & 2.07 & 0.24 & 0.16 & 3.02 \\
\hline $\begin{array}{c}\text { Bearing without } \\
\text { lubrication after 60 } \\
\text { minutes of operation }\end{array}$ & 2.35 & 0.30 & 0.18 & 3.88 \\
\hline
\end{tabular}

Table 6. Statistical parameters determined based on the amplitude of order No. 1 - envelope band $1600-1900 \mathrm{~Hz}$

\begin{tabular}{|c|c|c|c|c|}
\hline & $\begin{array}{c}R M S D \\
{\left[\mathrm{~m} / \mathrm{s}^{2}\right]}\end{array}$ & $\begin{array}{c}\Delta A_{\max } \\
{\left[\mathrm{m} / \mathrm{s}^{2}\right]}\end{array}$ & $\begin{array}{c}r R M S D \\
{[-]}\end{array}$ & $\begin{array}{c}r \Delta A_{\max } \\
{[-]}\end{array}$ \\
\hline Undamaged bearing & 0.11 & 0.11 & 0.04 & 0.37 \\
\hline $\begin{array}{c}\text { Bearing without } \\
\text { lubrication }\end{array}$ & 1.10 & 0.95 & 0.55 & 2.08 \\
\hline $\begin{array}{c}\text { Bearing without } \\
\text { lubrication after 30 } \\
\text { minutes of operation }\end{array}$ & 1.11 & 1.02 & 0.56 & 2.22 \\
\hline $\begin{array}{c}\text { Bearing without } \\
\text { lubrication after 60 } \\
\text { minutes of operation }\end{array}$ & 0.96 & 0.79 & 0.50 & 1.71 \\
\hline
\end{tabular}

\subsection{Temperature impact}

Temperature impact is an important aspect in the presented analysis of amplitudes of characteristic orders. The analysis of the temperature impact on the amplitudes of characteristic orders has been performed. Fig. 15 presents the amplitudes of the meshing order during the system heating; successive curves are determined for the following gearbox temperatures: black $30^{\circ} \mathrm{C}$, green $32^{\circ} \mathrm{C}$, red $35^{\circ} \mathrm{C}$, grey $37^{\circ} \mathrm{C}$. The amplitude dispersion for various temperatures is the greatest in case of the highest rotational speed, that is the system with the least load. The order amplitude grew twofold between the gearbox temperatures of $30^{\circ} \mathrm{C}$ and $37^{\circ} \mathrm{C}$.

The next step involved an analysis of the temperature impact on the order amplitudes of the signal envelope in the $200-600 \mathrm{~Hz}$ band. Fig. 16 presents the curves for order No. 1 for various temperatures of the correctly functioning gearbox. In this case, the amplitude related to temperature increased almost threefold.

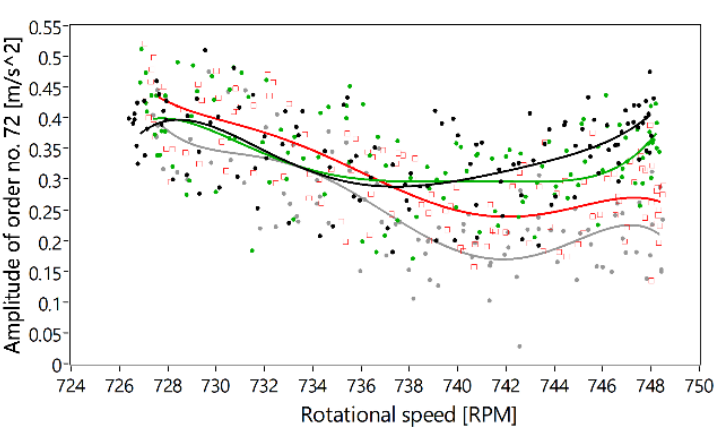

Fig. 15. Amplitude of order No. 72 as a function of rotational speed of the vibration acceleration signal for various gearbox temperatures: black $30^{\circ} \mathrm{C}$, green $32^{\circ} \mathrm{C}$, red $35^{\circ} \mathrm{C}$, grey $37^{\circ} \mathrm{C}$; undamaged bearing

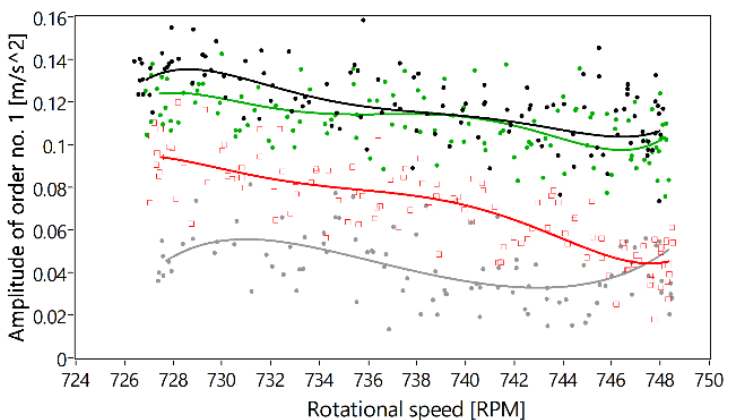

Fig. 16. Amplitude of order No. 1 as a function of rotational speed of the vibration acceleration signal envelope (band $200-600 \mathrm{~Hz}$ ) for various gearbox temperatures: black $30^{\circ} \mathrm{C}$, green $32^{\circ} \mathrm{C}$, red $35^{\circ} \mathrm{C}$, grey $37^{\circ} \mathrm{C}$; undamaged bearing

Further figures (Fig. 17, Fig. 18) show the FTF order No. 0.41 amplitudes of the envelope signal during the system heating for temperatures from $30^{\circ} \mathrm{C}$ to $37^{\circ} \mathrm{C}$ for the correctly functioning bearing (Fig. 17) and for the damaged bearing (Fig. 18) immediately after the damage was introduced.

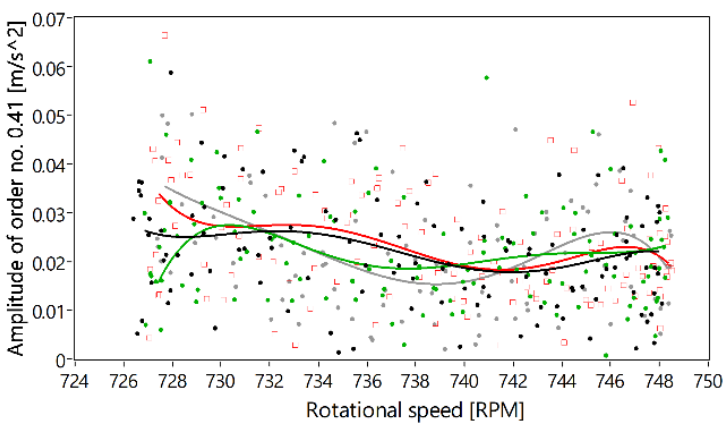

Fig. 17. Amplitude of order No. 0.41 as a function of rotational speed of the vibration acceleration signal envelope (band $200-600 \mathrm{~Hz}$ ) for various gearbox temperatures: black $30^{\circ} \mathrm{C}$, green $32^{\circ} \mathrm{C}$, red $35^{\circ} \mathrm{C}$, grey $37^{\circ} \mathrm{C}$; undamaged bearing 


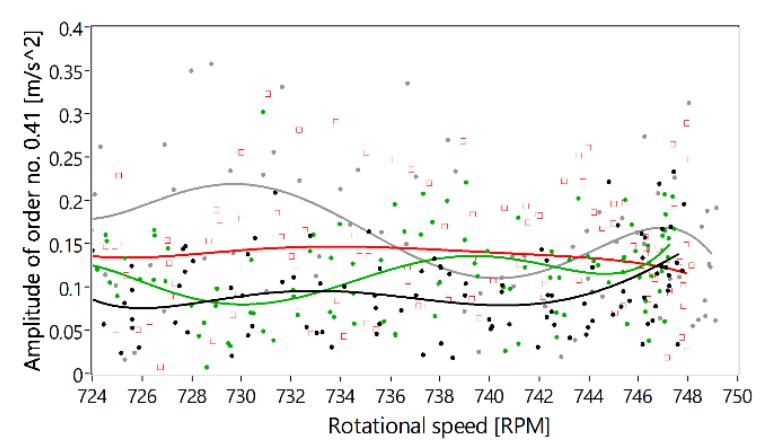

Fig. 18. Amplitude of order No. 0.41 as a function of rotational speed of the vibration acceleration signal envelope (band $200-600 \mathrm{~Hz}$ ) for various gearbox temperatures: black $30^{\circ} \mathrm{C}$, green $32^{\circ} \mathrm{C}$, red $35^{\circ} \mathrm{C}$, grey $37^{\circ} \mathrm{C}$; damaged bearing

No significant amplitude differences were recorded in case of this FTF characteristic order for the correctly functioning system. The amplitude value is relatively small in comparison with other parameters. However, the impact for this parameter in a damaged bearing is significant - the amplitude vales change more than twofold under the impact of temperature.

\section{SUMMARY}

The paper presents a method of diagnosing the rolling bearings installed in machines operating at variable loads. The proposed method is based on the analysis of curves that describe the amplitude change of characteristic orders as a function of load. The curves of characteristic orders are determined for the analysed envelope signal in bands determined by means of spectral kurtosis.

A diagnostic experiment was conducted on a testing rig, in which a damage of the planetary gearbox was introduced. The damage involved a removal of grease from the bearing which frequently occurs in industrial conditions when the seals are damaged. The gearbox ran at variable sinusoidal loads.

A method of using single-number statistical parameters for the rolling bearing diagnostics was proposed. Such parameters describe deviations of analysed orders amplitudes from the standard curve recorded during the correct bearing operation.

The possibility of diagnosing the gearbox rolling bearings based on the meshing modulation signal was also analysed. The analyses prove that it is possible to analyse the gearbox based on the envelope signal from the meshing band.

The impact of temperature on the amplitudes of characteristic orders was analysed. The temperature impact on the amplitudes of characteristic orders and on the shape of curves that describe the change of orders amplitudes caused by load is significant. This indicates the need for diagnostics with the use of the proposed methods under the conditions of constant temperature.

\section{SOURCE OF FUNDING}

The project was financed by the Polish Ministry of Science and Higher Education [project No. 16.16.130.942].

\section{REFERENCES}

1. Tandon N, Choudhury A. A review of vibration and acoustic measurement methods for the detection of defects in rolling element bearings. Tribology International. 2000; 32(1999):469-80.

https://doi.org/10.1016/S0301-679X(99)00077-8

2. Zhou L, Duan F, Corsar M, Elasha F, Mba D. A study on helicopter main gearbox planetary bearing fault diagnosis. Applied Acoustics. 2019; 147: 4-14. https://doi.org/10.1016/j.apacoust.2017.12.004

3. Klausen A, Robbersmyr KG, Karimi HR. Autonomous Bearing Fault Diagnosis Method based on Envelope Spectrum. IFAC-PapersOnLine. 2017; 50(1):13378-83. https://doi.org/10.1016/j.ifacol.2017.08.2262

4. Baydar N, Ball A. Detection of gear failures via vibration and acoustic signals using wavelet transform. Mechanical Systems and Signal Processing. 2003 Jul 1; 17(4):787-804. https://doi.org/10.1006/MSSP.2001.1435

5. Batko W, Barański R. Wavelet Transfer Function in the Analysis of the Influence of a Palm Grip on Actual Vibrations of an Upper Limb. International Journal of Occupational Safety and Ergonomics. 2007; 13(4): 355-365. https://doi.org/10.1080/10803548.2007.11105093

6. Antoni J, Randall RB. The spectral kurtosis: Application to the vibratory surveillance and diagnostics of rotating machines. Mechanical Systems and Signal Processing. 2006;20(2):308-31. https://doi.org/10.1016/j.ymssp.2004.09.002

7. Randall RB, Antoni J. Rolling element bearing diagnostics-A tutorial. Mechanical Systems and Signal Processing. 2011;25(2):485-520. https://doi.org/10.1016/i.ymssp.2010.07.017

8. Wang Y, Tse PW, Tang B, Qin Y, Deng L, Huang T. Kurtogram manifold learning and its application to rolling bearing weak signal detection. Measurement: Journal of the International Measurement Confederation. 2018;127(4):533-45.

https://doi.org/10.1016/j.measurement.2018.06.026

9. Wodecki J, Michalak A, Zimroz R. Optimal filter design with progressive genetic algorithm for local damage detection in rolling bearings. Mechanical Systems and Signal Processing. 2018;102:102-16. https://doi.org/10.1016/j.ymssp.2017.09.008

10. Yu K, Lin TR, Tan J, Ma H. An adaptive sensitive frequency band selection method for empirical wavelet transform and its application in bearing fault diagnosis. Measurement: Journal of the International Measurement Confederation. 2019;134:375-84. https://doi.org/10.1016/j.measurement.2018.10.086

11. Cioch W, Krzyworzeka P. Vibration analysis of running-up turbine engine GTD-350. Diagnostyka. 2007; 4(44): 125-130.

12. Burdzik R, Konieczny Ł, Warczek J, Cioch W. Adapted linear decimation procedures for TFR analysis of non-stationary vibration signals of vehicle suspensions. Mechanics Research Communications. 2017; 82:29-35.

https://doi.org/10.1016/j.mechrescom.2016.11.002 
13. Zimroz R, Bartkowiak A. Two simple multivariate procedures for monitoring planetary gearboxes in non-stationary operating conditions. Mechanical Systems and Signal Processing. 2013; 38(1): 237247. https://doi.org/10.1016/j.ymssp.2012.03.022

14. Pawlik P, Lepiarczyk D, Dudek R, Ottewill JR, Rzeszuciński P, Wójcik M, et al. Vibroacoustic study of powertrains operated in changing conditions by means of order tracking analysis. Eksploatacja i Niezawodnosc - Maintenance and Reliability. 2016; 18(4): 606-612.

https://doi.org/10.17531/ein.2016.4.16

15. Dabrowski D. Condition monitoring of planetary gearbox by hardware implementation of artificial neural networks. Measurement: Journal of the International Measurement Confederation. 2016; 91: 295-308. https://doi.org/10.1016/j.measurement.2016.05.056

16. Popiołek K, Pawlik P. Diagnosing the technical condition of planetary gearbox using the artificial neural network based on analysis of non-stationary signals. Diagnostyka. 2016; 17(2): 57-64.

17. Stępień B. A Comparison of Classical and Bayesian Interval Estimation for Long-Term Indicators of Road Traffic Noise. Acta Acustica united with Acustica. 2018; 104(6): 1118-29. https://doi.org/10.3813/AAA.919276

18. Jaramillo VH, Ottewill JR, Dudek R, Lepiarczyk D, Pawlik P. Condition monitoring of distributed systems using two-stage Bayesian inference data fusion. Mechanical Systems and Signal Processing. 2017; 87: 91-110.

https://doi.org/10.1016/j.ymssp.2016.10.004

19. Urbanek J, Barszcz T, Strączkiewicz M, Jablonski A. Normalization of vibration signals generated under highly varying speed and load with application to signal separation. Mechanical Systems and Signal Processing. 2017; 82: 13-31. https://doi.org/10.1016/j.ymssp.2016.04.017

20. National Instruments Corporation. LabVIEW, Order Analysis Toolkit User Manual. 2005

21. Xu X, Zhao M, Lin J, Lei Y. Envelope harmonic-tonoise ratio for periodic impulses detection and its application to bearing diagnosis. Measurement. 2016; 91: 385-97.

https://doi.org/10.1016/j.measurement.2016.05.073

22. Antoni J. The spectral kurtosis: A useful tool for characterising non-stationary signals. Mechanical Systems and Signal Processing. 2006; 20(2): 282307. https://doi.org/10.1016/j.ymssp.2004.09.001

23. Pawlik P. Single-number statistical parameters in the assessment of the technical condition of machines operating under variable load. Eksploatacja i Niezawodnosc - Maintenance and Reliability. 2019; 21(1): 164-169. https://doi.org/10.17531/ein.2019.1.19

Received 2019-05-18

Accepted 2019-08-06

Available online 2019-08-12



Pawel PAWLIK, received $\mathrm{PhD}$ degree in Faculty of Mechanical Engineering and Robotics from AGH University of Science and Technology, Cracow, Poland, in 2013. In the scientific work he builds vibrodiagnostic monitoring systems and develops methods of signals processing. $\mathrm{He}$ is also involved in the development of non-classical methods of uncertainty assessment. 